\title{
Values in Practice : Change and Continuity in Luangan Ritual Performance
}

\section{Herrmans, Runa Isabell}

Springer

2017-05

Herrmans , R I 2017 , Values in Practice : Change and Continuity in Luangan Ritual

Performance . in C Arenz, M Haug, S Seitz \& O Venz (eds), Continuity under change in

Dayak Societies . Edition Centaurus - Sozioökonomische Prozesse in Asien, Afrika und

Lateinamerika , Springer, Wiesbaden , pp. 191-210 . https://doi.org/10.1007/978-3-658-18295-3_8

http://hdl.handle.net/10138/311422

https://doi.org/10.1007/978-3-658-18295-3_8

unspecified

acceptedVersion

Downloaded from Helda, University of Helsinki institutional repository.

This is an electronic reprint of the original article.

This reprint may differ from the original in pagination and typographic detail.

Please cite the original version. 


\title{
Values in Practice: Change and Continuity in Luangan Ritual Performance
}

Isabell Herrmans, University of Helsinki

isabell.herrmans@helsinki.fi

\section{Author Information}

Isabell Herrmans received her PhD. in Social and Cultural Anthropology from the University of Helsinki in 2011. Currently she works in the research project 'Contested Values in Indonesia: Value Creation and Value Relations in Contemporary Borneo,' at the University of Helsinki, financed by the Academy of Finland. She has done fieldwork among the Luangan of Indonesian Borneo since 1993. Her published works include the monograph 'Ritual Retellings: Luangan Healing Performances through Practice' (2015, Berghahn Books). Her research focuses on rituals, animism, Indonesian politics of religion, values, and human-environment relations.

\begin{abstract}
This article explores Luangan conceptions of the good and desirable as conveyed and negotiated through ritual performance under conditions of rapid change in Indonesian Borneo. It does so by exploring ritual practice in two ethnographic field sites: an East Kalimantan village with a marked ethos of social solidarity and a relational ontology, and a nearby transmigration camp where rituals are influenced by increasing individualism, shamanic professionalization, monetization of the local ritual economy, and objectification of local tradition. Focusing on different ways of sharing communal meals and paying for ritual services in these locations, the article contrasts a ritual economy based on maintaining kin relations with what some Luangan pejoratively call "business rituals" (belian usaha), referring to rituals financed by gambling that may be prolonged for months on end, in which audience participation is divided between close family and outside spectators. While these examples reflect shifting and conflicting value orientations among the Luangan, the article argues that the latter may simultaneously be understood as a strategic act, serving to maintain precisely some of those values that it is taken to contradict.
\end{abstract}




\section{Introduction}

In this article I explore cultural values, in the sense of conceptions of "the good and desirable" (Robbins 2012; 2013), as conveyed through ritual performances among the Luangan Dayak in the border area between the provinces of East and Central Kalimantan. This is an area which has undergone extensive environmental, economic, and social change in recent years, occasioning a shift in value orientations. Taking as a vantage point a Luangan myth in which eight shamans - so powerful that they could awaken people from death, so popular that they could live on ritual salaries alone were killed because they failed to take care of their children, the article examines a widely felt tension between ethical and economic values as reflected in ritual activities (Lambek 2012). Used as a metacommentary, the myth brings up a theme and question both timeless and current: how to balance what Bloch and Parry (1989) call the long-term reproduction of the socio-cosmic order with the shortterm advancement of personal gain, or how to choose between the needs of one's immediate family, and those of the community, or society, at large.

I explore these questions by comparing ritual performances in two ethnographic field sites. The first is Sembulan, an East Kalimantan Luangan village where I have conducted fieldwork since 1993, where rituals are informed by an ethos of social solidarity and a relational ontology. The second site is Anan Jaya, a nearby transmigration camp which I have visited intermittently between 1997 and 2015, where local Luangans live alongside an ethnically mixed population of Javanese and non-local Dayak migrants, and rituals are influenced by increasing individualism, shamanic professionalization, monetization of the local ritual economy, and objectification of local tradition. By focusing on different ways of sharing communal meals and paying for ritual services in these two locations, I contrast a ritual economy based on maintaining kin relations and community integration with one associated with what some Luangan pejoratively call "business rituals," referring to rituals that may be prolonged for months on end as and because they are financed through gambling, and in which audience participation has become increasingly differentiated for close family and outside spectators. While these examples are presented to reflect shifting and conflicting value orientations among the Luangan, I argue that the latter example may simultaneously be understood as a strategic act, serving to maintain precisely some of those values that it is taken to contradict. 
The article is based on ethnographic fieldwork conducted for roughly two years with Luangans living in the border area between Central and East Kalimantan, an area I refer to as the central Luangan area (Herrmans 2015, p. 30-32). ${ }^{1}$ This is a rather remote upriver region, covered by secondary and, to a rapidly decreasing extent, primary rainforest, in which several villages could be reached only by foot when I first visited them. Starting a few years ago, extensive oil palm plantations have come to cover much of the region, and most villages are now connected by roads. This area is also the mythological homeland of the Luangan, where many events in a corpus of Luangan origin myths (tempuun) took place, where Mount Lumut, the realm of the dead, is located, and from where various ritual practices are said to originate.

\section{The Myth as a Commentary on a Problem}

They were magnificent, the eight shamans. Women and men. When treating a patient that patient would not not-become cured. So miraculous were they that they could awaken people who were already buried, awaken the dead. They were called to perform belian healing rituals from all over, starting off in the village where they lived, going on to neighboring villages, and then to places further and further afield. They had no need to grow their own rice but lived on meat from animals sacrificed in rituals and rice received as ritual salaries. Even when they had children they did not stop, the children being left to be brought up by their grandparents, fed by relatives.

As we might guess, this would sooner or later turn against them. As they grew older, the children of the eight shamans started to ask questions about their parents. Don't we have any real parents? What happened to them? Learning that they did indeed have parents, but that these had left them, "hungry, starving," a long time ago, no one having seen them for years, the children became so angry that they ordered that their parents be killed. Hence it came to be that Putes Lalung Jues and Joreh Lalung Tokah, two assassins hired by the children, severed the heads of the eight shamans.

According to the Luangan myth of ritual paraphernalia - a myth regularly chanted during some major

\footnotetext{
${ }^{1}$ Fieldwork among the central Luangan was conducted intermittently between 1993 and 2015, with the longest periods in 1993 (6 months) and 1996-1997 (12 months), and shorter periods in 1998, 2007, 2011, 2014, and 2015. The fieldwork was conducted together with Kenneth Sillander.
} 
Luangan rituals (buntang and nalin taun community rituals), here modified by me from a version told by the late shaman Kakah Ramat - it was from the remains of the eight shamans that various sorts of incense wood, flowers, and plants that are used to make ritual paraphernalia came into existence, some of the potency of the eight shamans thus being transferred to later-generation shamans. ${ }^{2}$ My interest in this article is not so much with the workings of ritual paraphernalia or the potency of objects, however, as with how the myth, through the story of the eight shamans, brings up a moral dilemma, the relevance of which seems to transcend time and space. ${ }^{3}$ Striking an almost Faustian chord, the myth presents the eight shamans as both marvelous (manget in the local language) and destructive, extremely successful in their trade, defeating death, but at the price of losing track of what is important in life, and of what ultimately sustains it.

In July 2011, in the small hamlet of Sembulan in an upriver area of East Kalimantan, the shaman Ma Kerudot is no less busy, even if he is certainly less omnipotent. As a six-day long belian buntang ritual, a combined thanksgiving and healing ritual, is about to end and as the ritual salaries of white plates, pieces of cloth and meat from animals sacrificed are displayed, he gives a speech, an account of what has been done during the ritual. He points out that he has worked as a belian, or shaman (the word belian is used by the central Luangan for both the ritual and the shaman), ${ }^{4}$ for 28 days in a row, performing four different rituals in the village without any rest in between. He is not the only shaman around to appoint, he reminds his audience, urging them to understand his predicament. He needs to tend to his fields as well, to get some sleep (rituals often go on for much of the night, and buntang rituals in the daytime too, not leaving many hours of rest for the shaman in charge).

\footnotetext{
${ }^{2}$ While I try to follow Kakah Ramat's words and expressions as accurately as possible in my retelling and translation of the myth, I have left out some sentences and included commentaries of my own.

${ }^{3}$ In this article I use the introduction of the myth to raise questions about value, leaving other themes and a more thorough analysis of the myth's contents for a future publication.

${ }^{4}$ I use the word shaman here in a general sense, as commonly employed in the Southeast Asian ethnography (e.g. Atkinson 1989; Sather 2001). A belian (or wara, death ritual specialist) may be defined as a shaman in the classical sense of a "ritual intercessor" (Sather 2001, p. 11), who is capable at will of passing "from one cosmic region to another" (Eliade 1964, p. 259). Like his or her Iban counterpart, a belian is "believed to dispatch his soul into invisible regions of the cosmos" and is thought to have "the power to direct [his soul's] movements and to perform deeds within these unseen regions with the help of personal spirit guides" (Sather 2001, p. 11). In contrast to Iban shamanism, spirit possession is not unheard of among Luangan shamans, but occurs occasionally, either spontaneously or as a result of the use of special techniques (most prominently during divination, preau). For most of the time, however, the "possession" by spirit familiars of belian shamans (the spirit familiars are said to enter, sua, the shaman) is an intentional and highly controlled endeavor - mainly about summoning them rather than possession in a stricter, trance-induced or other sense - and not appropriately described as mediumship.
} 
Ma Kerudot is not alone in being busy with ritual work. Among his Benuaq and Tunjung neighbors, ${ }^{5}$ major rituals may go on for weeks, or, not infrequently today, months on end. Each time that I have travelled through areas inhabited by Benuaq or Tunjung on my way to and from Luangan villages located further inland in recent years, there has been a months-long ritual going on in some village, either a nalitn tautn $^{6}$ community ritual or a kwangkai secondary mortuary ritual, and often several at the same time. In particular, the time between the rice harvest and the clearing of new fields in June and July has become something of a ritual season (due to my children's school holidays, this is also the time at which I have most frequently visited the area in recent years). In June 2015 three extended kwangkai rituals were held simultaneously in the village of Sekolaq Darat, inhabited by a majority of Tunjung, and its vicinity, while a nalitn tautn ritual was performed in Payang, which is a Benuaq village an hour's drive away (there were probably also other rituals in other villages nearby that I did not hear about during my short stay).

Staging such extended rituals demands the services of a large number of ritual experts, especially toward the end of a ritual, when the program intensifies. At the same time the number of trained shamans is declining in many places, and ritual experts often have to be invited from quite far away. ${ }^{7}$ This was part of the problem in the village of Payang, where the ritual had already gone on for several months by July 2015, mostly with minimal activity as all available shamans were busy elsewhere. When I visited there was only one shaman present, asleep under his mosquito net at the wooden platform that constituted the village marketplace and that had now been converted to a ritual arena, housing both the sponsoring family and the shaman and his wife. For the sake of the anthropologists, the shaman, an elderly blind man, was woken up, and asked to resume his ritual activities. He sat down by the ritual paraphernalia that had been assembled in the middle of the space and chanted for a while,

\footnotetext{
${ }^{5}$ The Benuaq and Tunjung live north of the central Luangan area where Ma Kerudot lives. Both the Benuaq and Tunjung have been categorized as Luangan (e.g. Weinstock 1983). The Luangan are not an ethnic group in the strict sense of the term, however, but a loosely bounded general category encompassing many subgroups whose members often do not use or even recognize the term for themselves. Especially in the central parts of the Luangan area, people do maintain a degree of self-identification as Luangan, however, based on sharing a common mythology and ritual tradition, which is seen to originate in the upper Teweh River area. Ma Kerudot himself would variously self-identify as Bentian or Luangan. ${ }^{6}$ The Benuaq say nalitn tautn, whereas central Luangan say nalin taun, which explains the discrepancy of spelling used in this article.

${ }^{7}$ Young people are often said to be unwilling to take up apprenticeship as shamans today, being attracted by more lucrative educational and occupational opportunities (cf. Haug 2010, p. 73), and disinclined to undergo the training to become a belian, which takes years of practice. Increasing conversion to Christianity is another reason for this situation. However, there are exceptions, especially in Central Kalimantan, where I have met several young men training to become shamans in recent years.
} 
and then went back to sleep. The family sponsoring the ritual had no clear idea when the ritual would or could be finished, or even whether it would actually become a nalitn tautn ritual as planned, or instead turn out to be a smaller bekeleeu ritual, due to lack of finances and the difficulty of engaging the required number of shamans (several people contacted were busy with other rituals). Among the ritual paraphernalia a portrait of President Jokowi was displayed in the hope that he or the government he represented would support the ritual financially in return for the support they had provided him in the election campaign the year before. While the ritual program was reduced to a minimum at the time of my visit, there was continuous gambling, the main source of funding for the ritual, going on outside, behind the ritual arena.

There are some significant differences, however, between Ma Kerudot's predicament and that of the shamans appointed to conduct such extended rituals as that described above in Payang. (It is worth noting that, since shamans from the area in which he lives are occasionally called to perform rituals among the Benuaq and Tunjung, Ma Kerudot could potentially be one of those appointed). As we shall see, being busy with ritual work means quite different things in different contexts and reflects differing value orientations.

Like in the myth, in which the activities of the eight shamans stand out as both extremely powerful and as morally questionable (and hence as ultimately destructive), Luangan living in Sembulan and many surrounding villages in what I call the central Luangan area, regard the extended rituals performed by some of the Benuaq and Tunjung - and some local variants influenced by them, such as the ritual performed in the nearby transmigration camp discussed later in the article - with a certain ambivalence. ${ }^{8}$ On the one hand, such rituals give local tradition visibility and legitimacy as adat (objectified tradition), an increasingly important notion in post-Reformasi Indonesia (see e.g. Davidson and Henley 2007; Reuter 2009; 2013), and especially in East Kalimantan where the local government has not recognized the local "religion," often called Kaharingan, as an officially approved religion (agama), unlike in Central Kalimantan, where it has been recognized as part of Hinduism, under the

\footnotetext{
${ }^{8}$ It should be noted here that not all Benuaq or Tunjung rituals are extended because of gambling and that there are nuances of commodification among the Benuaq and Tunjung as well as among the central Luangan. There is a difference between paying shamans in cash, which most Benuaq do today, and extending rituals because of gambling, which some Benuaq reject (Haug, personal communication). Also, while central Luangans often attribute so-called "business rituals" to the Benuaq and Tunjung, many Benuaq ascribe them mainly to the Tunjung (Haug 2010, p. 74).
} 
label Hindu-Kaharingan (see Herrmans 2015, p. 63-66). ${ }^{9}$ The rituals have a festival-like allure, drawing people from afar to participate, showcasing Benuaq or Tunjung tradition, at times with financial support received from the regional government (especially during election campaigns, when candidates are eager to sponsor rituals so as to gain votes). But on the other hand, the rituals are simultaneously seen to contradict some values regarded as essential to that tradition, a criticism also voiced by some Benuaq and Tunjung ritual experts (Venz, personal communication). Reflecting their hesitant stance toward them, central Luangan dismiss such rituals as "business rituals" (belian usaha), referring to how they are financed through gambling and how that practice is allowed to influence the ritual format, expressing the notion that the commercialization of rituals and the potential political motives involved influence the moral economy in a negative way. ${ }^{10}$

The revenue generated by gambling can indeed be substantial in some areas and maximization of such revenue is a main reason for extending rituals. Michaela Haug (2010, p. 74) has described how gambling operators may earn up to 10 million IDR $^{11}$ per day during extended death rituals among the Tunjung living close to the capital of the regency of Kutai Barat. There may be up to twenty such operators present during a ritual and the ritual may go on for several weeks, or even months. Similarly, Morgan Harrington (2014, p. 109) describes how the gambling syndicates that increasingly sponsor mortuary rituals among the Siang in Central Kalimantan may generate hundreds of millions of IDR. In the past, the costs for Siang mortuary rituals (totoh), which usually were staged for multiple deceased people, were shared by an extended kin network, while the rituals today are arranged mainly for individuals, with the burden of the costs placed on fewer people, which has led to the Siang seeking funding from non-Siang gambling syndicates (Harrington 2014, p. 105). According to Harrington (ibid.), "Siang cosmology can no longer be reproduced without involvement of external interests."

Often appointed for several weeks or even months, shamans employed to conduct such extended rituals among the Benuaq or Tunjung may be paid several million IDR (as claimed by central Luangan

\footnotetext{
${ }^{9}$ There are only six officially recognized religions (agama) in Indonesia, where those "not yet" in possession of a religion (orang yang belum beragama) have been considered primitive animists, lacking in national consciousness (see Atkinson 1987, p. 174; Picard 2011). In the Muslim-governed province of East Kalimantan, Kaharingan is considered to be a set of "beliefs" (kepercayaan) only, something which has caused discontent among Luangan living there who are forced to become nominally Christian in order to receive identity cards, for example. Hindu-Kaharingan received recognition as a Hindu sect in Central Kalimantan in 1980 as a result of a long struggle led by the Ngaju (see Schiller 1997. p. 109-131). ${ }^{10}$ Although belian refers to life rituals, death rituals are no different in this respect and the expression is also used for them. ${ }^{11}$ Equaling US\$1100 in 2004.
} 
shamans, in some cases with considerable envy). ${ }^{12}$ The practices of extending rituals because of gambling and engaging shamans from many different, often far-flung, regions during a single ritual has also led to a degree of professionalization of shamanic practice (cf. Donzelli 2007, p. 142 for a similar situation among the Toraja of Sulawesi), with some shamans travelling around from ritual to ritual, somewhat like the eight belian of the myth (even if few of them are able to live on ritual salaries alone, they, and accompanying family members, are provided with free food and cigarettes during the course of a ritual). At the same time the ritual content has become somewhat standardized and watered down. This is, as we shall see, in rather sharp contrast to the situation in Sembulan, where Ma Kerudot mostly works, and where gambling is not practiced during rituals. (Gambling, in a much more modest form and degree, was in the past part of larger rituals in the central Luangan area, but is not presently practiced in Sembulan at all.)

\section{The Value of Social Relations}

Sembulan is a small village located in a thinly populated headwater area where rivers are shallow and mostly non-navigable. When I first visited Sembulan in the early 1990s, the village, like many other central Luangan villages, could only be reached by foot. The inhabitants made their living from shifting cultivation, in combination with hunting, fishing, and the gathering of forest products. They were largely economically self-sufficient, obtaining cash mainly from the sale of rattan, which they have cultivated in their swidden fields for over a century. Most of them shifted residence between their swidden fields, where they lived in small temporary houses (blai ume), and the village, where they lived in either small individual family houses (blai), or larger multi-family houses (lou or lou solai). There was a strong ethos of social solidarity between kin and neighbors, evidenced through the sharing of food and game and through participation in collective work parties and remarkably frequent belian rituals. All inhabitants identified themselves as Kaharingan, adherents of the local "religion." Conforming to what could be described as a relational ontology, in the understanding of Tim Ingold (2006) and Nurit Bird-David (1999), personhood and social relations were extended to include nonhuman beings, especially the various spirits of the local landscape.

\footnotetext{
${ }^{12}$ According to people I worked with, 2-3 million IDR was a minimum for rituals lasting over a week. Among the Dusun in Central Kalimantan I was told that there is a standard price of 2 million IDR paid for conducting a major siwah ritual (lasting eight days), set by the regional branch of the Hindu Kaharingan Council.
} 
Around 2009 oil palm companies entered the area surrounding Sembulan, quickly converting much of the forest around the village into oil palm plantations. Some inhabitants sold their land quite willingly, despite complaining that prices were low, while others tried to hold on to it, but were eventually forced to sell anyway due to the fear that if they did not do so, someone else would, thus robbing them of the potential profit. As local land rights, which are based on clearing communal forest for cultivation, are inherited bilaterally and often overlap, conflicts over ownership became frequent. Before these could be settled by local elders, or even brought to the negotiation table, the companies that had claimed the land rushed to burn the forest, preparing it for the oil palm plantations. As elsewhere in Indonesia, and following a colonial pattern, "plantation managers favored migrant workers over 'locals,"” because migrants, being totally dependent on the income from plantation work, were "more easily disciplined" (Li 2014, p. 170). Beside the small sum paid for the land, Luangans receive a 20 percent share of the profit of oil palm crops on land that they have sold. ${ }^{13}$

With the arrival of oil palm cultivation, a price was put not only on land, but also on game animals (for which a market developed) and this, along with associated generalized monetization processes, affected local social relations remarkably quickly: Within a few years, several villages had changed from largely exchange-based systems into market-based ones, leading to a dramatic decrease in kin and community solidarity. This is in sharp contrast to how Jérôme Rousseau (2013) describes the disappearance of the traditional practice of distributing meat among the Kayan in the 1970s, which, apparently because it was not associated with the same general economic processes, had no impact on other aspects of social life. While in the 1990s, when I started my work in the central Luangan area, game was shared between the members of a community, or at least an extended family (which generally amounts to the same thing in smaller villages like Sembulan, where most people are closely related), today almost all game is sold, even between close family members, something which was unthinkable before. "Without money you cannot survive today," inhabitants say. Even if the central Luangan have a long history of trade (of rattan, resins, beeswax and other forest products sold when the market price was favorable), it seems that the arrival of oil palm triggered what can be described as a shift from a "market-as-opportunity" to a "market-as-compulsion" approach (Brenner 1985; Wood

\footnotetext{
${ }^{13}$ People selling land to the companies actually maintain ownership over 20 percent of the sold land, and receive the profit of the yields of this land. However, fees for fertilizers etc., provided by the companies, are deducted from this sum.
} 
2002; Li 2014, p. 6). With money received from the sale of land, almost every family bought a motor cycle, which, along with the simultaneous arrival of roads, allowed them to reach new markets that appeared around the oil palm camps, further facilitating this kind of shift. At the same time, more and more people have stopped hunting, becoming "too lazy," as some say, and increasingly dependent on store bought food.

However, this development has not affected the ritual economy thus far. On the contrary, it has quite deliberately been kept out of it. Aside from meat and cloth, shamans are mainly compensated for ritual work with dozens of ordinary white, store-bought plates. These have partly replaced the gongs and Chinese jars previously used for the same purpose, but which now, due to increased market value, have either been sold to downriver merchants or are kept out of circulation. Stored in large piles lined up along the walls of most shamans' and elders' houses, the plates provide a physical representation of the value of the act of giving them, and of reciprocal relations, in a way that way money, usually spent immediately, does not (cf. Lounela this volume). To cite Michael Lambek (2013, p. 155), whose take on value as generated through human activity I draw on in my analysis, the plates "store (or symbolize) the value of the acts [here of giving and of receiving, and of social relations] rather than being fully or purely valuable in and of themselves, let alone on the market." Even people who have converted to Christianity often choose to pay fines and compensation to people helping out during rituals, including funerals and weddings, with plates rather than money, thus marking the activity as one pertaining to ethical rather than economic value.

During my fieldwork in the late 1990s, the central Luangan often described themselves as rich in plates, not in money. In a similar way, they prided themselves in always providing visitors with food for free, in contrast to other areas where one must pay for rice (Sillander 2004, p. 289). Interesting here is the fact that plates do have a price, both when bought from downriver markets and within the local economy of valuables. In 2015 the price of a box of six dozen plates had gone up to 450,000 IDR, ${ }^{14}$ while one dozen plates still equaled one Chinese jar in the local symbolic economy, as decided by local leaders (manti) at some point in the past. In this sense, the argument sometimes presented to me that the Luangan use plates instead of money because they have comparatively little income does not tell the whole truth. It is also worth noting that plates cannot be re-sold locally, but are only used to pay for

\footnotetext{
${ }^{14}$ Equaling US\$35 in 2015.
} 
ritual services, as fines, or in marriage transactions. In addition, ritual participants often bring a few plates, along with some sugar, coffee, rice, or other food items, as a contribution to cover the costs of a ritual to the family arranging it, contributions which today often are carefully listed in notebooks. The use value of plates is also limited, as there are far more plates in circulation than are needed for the purpose of serving food, even during large rituals when there may be over a hundred guests present. For the central Luangan, being rich in plates entails being rich in social relations (the social significance of plates in this respect being comparable to gifts), with the price paid for plates and the trouble involved in transporting them upriver, especially before roads were built, adding to the value attributed to the maintenance of social relations.

A crucial aspect of plate distribution is their ceremonial display. Before the plates are given as salaries to shamans and others who have helped out with ritual tasks, and in some cases to all members of the ritual audience, piles of plates are spread across the floor, along with pieces of cloth and meat from sacrificial animals, and the number of plates in the piles are counted and re-counted, often repeatedly. A note with each receiver's name is then put on top of each pile, together with a small bill and some turmeric (a cooling substance); the leading shamans receiving the most, with lesser amounts being given to the shamans' assistants (penyempatung), those who have prepared the ritual paraphernalia and offerings (pengeruye) and other people that contributed. This ceremonial display is accompanied by speeches, which describe what has been done during the ritual, how many animals have been sacrificed, as well as the level of compensation due to those who have helped out. The speeches and the display of plates may be seen to serve, in Lambek's interpretation of Rappaport's take on ritual (1999), to establish "the criteria by which ethical judgement can take place" (Lambek 2012, p. 348), by making the importance of the Luangans" own actions "visible" or "recognizable" (Strathern 1988, in Graeber 2001, p. 47) both to themselves and to the spirits to whom the ritual work is ultimately dedicated (cf. Sillander 2004, p. 302-303). [Insert photograph 1 here]

Plate distribution and ritual sharing of food, to which I will turn next, are not only templates for value, however, but form productive acts through which Luangan relationality is actively constituted and affirmed. During major rituals long rows of plates with cooked meat from sacrificial animals, along with banana leaf packages or bowls of rice, are laid out across the floor and served to all ritual participants, humans and spirits alike (spirits first, then humans), often several times during certain 
days of the ritual, and usually after lengthy speeches. Similarly, each night of a larger ritual usually ends with the distribution of plates of sweet sticky rice, various cakes, and pieces of barbecued chicken to everyone present, this food having been presented as offerings (okan penyewaka) to the spirit helpers earlier in the evening. Like plate distribution, such display and collective sharing of food brings Luangan relationalism into being, indeed representing a precondition for it beyond instigating it, as relatedness is essentially acquired - kin relations, for instance, being as much based on "practical association," as on pre-established connection through blood or affinal kinship (Sillander 2011, p. 155; cf. Bird-David 1999, p. 73). As Lambek (2013, p. 147) states, "formalized acts of this kind are not merely representations of some prior state of action, after the fact, but are themselves socially constitutive and consequential - acts that create the facts." Like the ceremonial display of plates, the display of food, and its presentation through the shamans' chants (mostly to spirits) and the speeches of elders or leaders (mostly to humans), is an essential element of the process of solidifying relationalism as a value, and of creating relationships. In this respect it is arguably even more important than the actual consumption of the food, which is often eaten hurriedly. [Insert photograph 2 here]

In a relational ontology such as that of the Luangan, in which personhood and sociality is extended to include not only human beings, but also non-human beings, especially spirits of different kinds (which are regarded as the elder siblings of human beings, as recounted in the myth of human origins and as frequently invoked in ritual chants), continuous engagement in kin-like relations, of which the sharing of food is an essential element, is conceived as a condition for what constitutes a good life (bolum buen in the local language), and for its central elements health and prosperity. It is through interrelation that the kinship is not only realized but sustained. This is also, in part, I propose, why belian rituals are so popular among the Luangan, occupying Ma Kerudot and other shamans with seemingly endless ritual work (I attended belian rituals approximately every second night during my fieldwork in the 1990s, and the frequency of rituals does not seem to have significantly decreased in much of the central Luangan area). Similar to trances and divination among the Nayaka of south India (Bird-David 2004, p. 336), a commitment to share and to continue sharing and living together is a central objective of belian rituals (Herrmans 2015, p. 232-237), which are not only about healing in a straightforward way, but also about maintaining and negotiating social relations with those that the Luangan share their environment with, be they humans or spirits. This is so because the maintenance of relations is perceived as a precondition for well-being, and a precaution, preventive of ill-health (even while excessive blurring of boundaries 
between human beings and spirits, or between the ritual and non-ritual domains, may be problematic and dangerous as well, as exemplified by the myth of ritual paraphernalia).

Unlike the eight belian of the myth, however, Ma Kerudot cannot live on ritual salaries alone. Like most of his neighbors, and Luangan shamans in general, he subsists on shifting rice cultivation, and receives most of his cash income not from shamanic work, but from cultivating rattan (and increasingly from the sale of oil palm crops). Prolonged ritual work - in Ma Kerudot's case the result of many shamans in Sembulan having died within a short time span, increasing the pressure on those alive - put him in a position of conflict. Since most people requesting his ritual services were related to him in one way or another, denying such services was difficult. At the same time, continuous ritual work put a strain not only on his strength, but on his and his family's subsistence. This is perhaps also why some Luangan shamans are eager to take the opportunity to perform rituals among the Benuaq or Tunjung when invited, welcoming payment in cash, even though this practice is in conflict with the values belian is understood to promote and the relational ontology that it constitutes. Values are, of course, often not unambiguously affirmed, especially in today's Luangan society due to the ongoing processes of monetization. Additionally, it can be observed that the relational obligations placed on Ma Kerudot conflicted with another widely held value in Luangan society (notably associated in important ways with the practice of shifting cultivation): that of autonomy (see Sillander 2011, p. 161-163).

\section{Monetization of the Ritual Economy}

A contrasting example to Ma Kerudot's case - and to ritual practice in Sembulan more generally - is a gombok death ritual performed in 2014. This exhibited some similar elements to so-called "business rituals," albeit in a rather reduced form as the ritual in question was only two weeks long. This ritual was performed in Anan Jaya, a village adjacent to a transmigration camp located some $15 \mathrm{~km}$ from Sembulan. Anan Jaya is inhabited by a mix of Javanese transmigrants and Dayak peoples of varying ethnic origin, among them local Bentian (part of those I call the central Luangan), as well as Benuaq. Anan Jaya was built on government initiative close to a large logging camp in the mid-1990s. Today logging activities have nearly stopped and many of the Javanese transmigrants have returned to Java. 
The death ritual described was directly influenced by Benuaq practice, a result of the fact that several members of the sponsoring family had Benuaq origins. ${ }^{15}$ Seven shamans had been summoned to perform the ritual, some of them locals (one from Anan Jaya and two from adjacent Bentian villages), while others were Benuaq from different regions. The house in which the ritual was performed was a standard white-painted wooden transmigration house, consisting of one rather small room with a kitchen attached at the back. One of the side walls of the house had been torn down for the occasion, visually connecting the inside space to a large wooden platform that had been built outside and covered by a plastic tarpaulin. Directly outside the house, on a small veranda, gongs and drums were suspended. While the shamans were gathered inside the house, preoccupied with ritual work, presenting food to the souls of the dead and escorting them to the death realms, most other people stayed outside on or near the platform, on which gambling of various sorts took place. At regular intervals people from the audience stepped up to the musical instruments and played short melodies, characteristic of gombok rituals.

Despite the fact that no visible or audible barrier separated the inside ritual space from the outside, a mental one clearly did. In the course of the ritual, only people closely related to the sponsoring family, or those engaged as ritual experts and their family members, entered the house, while others remained outdoors, participating in or watching dice and other games, betting on cockfighting that was going on behind the house, or hanging about the warung (commercial food stalls) that had been erected along the dirt road in front of the house. While constant cooking by the hosts was going on both in the kitchen and outside the house, with large woks containing meat, vegetables, and rice continuously simmering on open fires, food was never publicly served during the ritual (except to the souls of the dead and other spirits, and to the shamans, who consumed part of this food after it had been presented to the spirits). Instead members of the extended family, including many relatives who had come from quite faraway places, were in turn asked into the kitchen to eat, while the outside spectators, local and nonlocal, who stopped by to gamble, ate in the food stalls. This was in sharp contrast to the practice in Sembulan and many other central Luangan villages, where failure to partake in collective eating is

\footnotetext{
${ }^{15}$ In documents used to apply for a permit from the police to conduct the ritual it was called a gombok/kenyau ritual, combining central Luangan and Benuaq designations. Unlike the Benuaq, the historically less stratified central Luangan use the term gombok for all secondary death rituals, mainly distinguishing based on whether a gombok involves water buffalo sacrifice or not, whereas Benuaq mainly distinguish between kenyau and kwangkai rituals, kwangkai being a more elaborate style of death ritual, in the past performed for "aristocrats" (Venz, personal communication). Gombok roughly correspond to kenyau, although an elaborate variant involving exhumation of the remains of the dead (gombok mpe selimat) more closely resembles kwangkai.
} 
perceived as an offense and as having potential consequences for people's well-being. ${ }^{16}$

For the sponsoring family, serving food to everyone present would most certainly have been a challenge spatially, economically, and socially (as there was a much higher number of passersby than usual for Sembulan, for example). At the same time, drawing as large a crowd as possible was highly desirable for several reasons. Economically, it helped to finance the ritual, as part of the money earned by the people arranging the gambling was paid to the sponsoring family, along with rent paid by stall keepers, while the cocks killed in cockfighting were given to the hosts to be served as food. Moreover, a lively state of "crowdedness" (ramai) is, like elsewhere in Indonesia (cf. Sutton 1996; Keeler 2001), understood as a value in itself, a factor associated with modernity and national belonging, and contributing to the success of the ritual in its own right. The ritual had a festive feel, with cars and motorcycles continuously coming and going, people stopping by to take part in gambling, or just to hang around, usually not paying much attention to the activities of the shamans. The principal exception to this lack of attention occurred on the last day when a water buffalo was killed in the customary way by stabbing it with spears on the main road, an activity which was preceded by several speeches and drew a large crowd of onlookers. However, cutting up and cooking the buffalo, in this particular case into a Javanese rawon dish rather than the watery and mild sauce usually made in Sembulan, took hours, and when the meal was finally ready late at night, most of the spectators, including many of the far-flung relatives, had already returned home.

In some ways, the ritual reflected an adaptation to living in a multi-ethnic environment with decreasing kinship obligations and an increasing monetization of the moral economy. The shamans appointed came from different areas with varying ritual traditions, which contributed to a sort of standardization and simplification of tradition, at least as seen from a central Luangan perspective. Chants were not as elaborate and there was not as much ritual paraphernalia as typical of central Luangan gombok involving water buffalo sacrifice (here we may note that the prolongation of rituals among part of the Benuaq and Tunjung does not necessarily mean that the actual ritual program is more elaborate: instead there are usually fewer program elements per day and proceedings are more drawn out). When my

\footnotetext{
${ }^{16}$ Not partaking in the ritual meal is seen to subject the people involved to tapen, a state of spiritual vulnerability that may entail soul loss. To promote participation in the final ritual meal when the buffalo was eaten, the kepala adat (head of tradition) of Anan Jaya, in his speech prior to its sacrifice, also urged members of the extended family to wait for the buffalo to be served before they went home. This nonetheless contrasts with the practice in other central Luangan villages where such invitations are extended to everyone present.
} 
fieldwork partner and I, in discussing the Anan Jaya ritual with some central Luangan friends later, expressed our surprise that there had been no large wooden ship (selewolo, or seleeu olo) to transport the souls of the dead to the death realms as is normally the case in gombok rituals in the central Luangan area, they were somewhat pleased to note that even we could spot "errors" being made, considering that evidence of the superiority of central Luangan tradition, not least as they knew that we had studied and participated in many rituals conducted by well-known central Luangan wara or death shamans (at that time already passed away). ${ }^{17}$

When paid for their services, the shamans officiating in the Anan Jaya ritual were not given piles of white plates as typical in Sembulan, but rather mostly received money (along with the usual pieces of cloth and chunks of meat). And yet, they were also presented with at least one white plate, just as everyone giving a speech during the ritual had to hold a white plate in their hand. The plates in these cases served to connect them to ancestral tradition and, at least symbolically, to a moral economy defined through relationalism and the maintenance of relations, including, most importantly, relations to ancestors. This is the opposite of the practice in central Luangan villages where a nominal sum of money is paid to shamans along with the plates, which indicates a partial connection to the market economy. This use of plates was seen as an absolute necessity and mentioned in several speeches as a guarantor of sincere intentions, materially linking people to an ongoing tradition of ritual performance and the negotiation of social relations through such performance. ${ }^{18}$

In this respect the ritual served to maintain precisely the sort of relational ontology it at times seemed to contradict. As a matter of fact, I suggest, the monetization and professionalization of ritual seen in Anan Jaya, and more markedly in some Benuaq and Tunjung villages, may be seen not only as an adaptation to modernity and to reform as a value, but also as a strategy to keep up a relational orientation in a social and political environment increasingly informed by capitalist relations and the individualism characterizing such relations (their motives hence extending beyond the identity politics associated with political decentralization and adat-ization in post-Reformasi Kalimantan). In such cases,

\footnotetext{
${ }^{17}$ Whereas such a ship is used in gombok rituals involving water buffalo sacrifice, it is not a necessary part of kenyau rituals (Venz, personal communication). In lesser central Luangan gombok rituals not involving water buffalo sacrifice, it is often replaced by a wooden miniature ship (sampan benawa) or an unopened areca palm inflorescence (sampan belawui).

${ }^{18}$ While practices involving plates, such as the practice of giving a plate containing some turmeric as a token of ritual participation, are widespread in connection with rituals and adat proceedings in Southeast Borneo, the distribution of a very large amount of plates as reward or compensation by the central Luangan appears to be unique.
} 
adjusting to changing socio-economic circumstances may be seen as a precondition for maintaining ancestral tradition as a transformative force and for allowing for the maintenance of the relational ontology upon which this tradition is based.

\section{Conclusion}

Ethics is always in practice yet also in question.

- Lambek (2012, p. 353)

Through examples from the villages of Sembulan and Anan Jaya, I have in this article highlighted the multiple levels of scale on which value negotiation by Luangans operates today. In Sembulan, a moral economy based on gift relations, epitomized by the large stacks of plates given in compensation for ritual services, is seen to stand in opposition to the "business rituals" of Anan Jaya and other villages, where the generation of profits from gambling has become a driving force. Especially now, as market relations have come to define most other aspects of central Luangan social life, keeping the ritual economy out of such relations appears to be an even more significant choice than it used to. Through a process which, following Joel Robbins and David Akin (1999, p. 24) could be termed "enclaving," the central Luangan have sought to protect a key reproductive social institution from "disruption by money and commoditization." While money is not barred from rituals as among the Kwaio of Melanesia (Akin 1999), using plates instead of money to compensate for ritual services puts ritual in a special position as a foundation and exemplar of value.

At the same time, adjusting rituals to changing living conditions can constitute just as much of a choice, as I have shown through the examples of Benuaq and Tunjung practice, and the ritual performed in Anan Jaya. While many central Luangan dismiss these rituals as mere business, for the families or communities arranging them, they serve not only to realize short-term interests or promote individual gain, but also to reproduce the long-term cosmological order. What has happened in this context is that ritual practice has become divided into two different spheres: a "private," but "disinterested," sphere, in which obligations to relatives and spirits are fulfilled through ritual activities performed "inside" the (sometimes non-existent) walls of a ritual house, and a "public" but "interested" sphere performed 
outdoors, which provides the material means to meet these obligations and caters to the requirements of making a living in modern Indonesia. Whether this sort of division, or the insulation of ritual from contamination by commoditization favored by people in Sembulan and other villages in the central Luangan area, better serves to maintain ancestral tradition as a vital force in society today remains to be seen. Among both "animist" Luangan and Catholic Benuaq, conversion to Protestantism, inimical to the practice of local rituals, has increased in recent years.

As Ma Kerudot indicated in his speech, balancing long-term and short-term cycles of reproduction is never uncomplicated. Value as generated through performative acts is necessarily situated and historically variable. It is also continuously challenged, and contingent on recognition, otherwise there would be little need for the Luangan to persistently single out the importance of relationalism as a criteria for ethical conduct. Social life, as Lambek (2012: 354) observes, "does not stand still and debate over the good life for human beings will never be fully resolved." Much of the appeal of the myth of the eight belian consists precisely in this kind of ambiguity (which it shares with myths more generally), in the conflict of its message. Condemned to death because they neglected to keep up their close relations even while pursuing the recognizably commendable goal of curing illness, the eight shamans of the myth are exemplars of amoral behavior. And yet they are also magnificent, a source of great empowerment, even for shamans today, through the ritual paraphernalia they transformed into, which provide present-day rituals with much of their efficacy. This is also why the myth translates so well into a commentary on the situation faced by many shamans today, sometimes nearly as busy as the eight belian of the myth and similarly caught between conflicting notions of the good and desirable, forced to make sometimes irreconcilable choices, if for no other reason than for maintaining ritual as a foundation of value.

\section{References}

Akin, D. (1999). Cash and Shell Money in Kwaio, Solomon Islands. In D. Akin and J. Robbins (Eds.), Money and Modernity: State and Local Currencies in Melanesia, pp. 103-130. Pittsburg: Pittsburgh University Press.

Atkinson, J. (1987). Religions in Dialogue: The Construction of an Indonesian Minority Religion. In R. S. Kipp and S. Rodgers (Eds.), Indonesian Religions in Transition, pp. 171-186. Tucson: University of Arizona Press. 
Atkinson, J. (1989). The Art and Politics of Wana Shamanship. Berkeley: University of California Press.

Bird-David, N. (1999). “Animism” Revisited: Personhood, Environment, and Relational Epistemology. Current Anthropology 40, S67-S91.

Bird-David, N. (2004). Illness-images and Joined Beings: A Critical/Nayaka Perspective on Intercorporality. Social Anthropology 12 (3), 325-339.

Bloch, M. and J. Parry. (1989). Introduction: Money and the Materiality of Exchange. In J. Parry and M. Bloch (Eds.), Money and the Morality of Exchange, pp.1-32. Cambridge: Cambridge University Press.

Brenner, R. (1985). Agrarian Class Structure and Economic Development in Pre-Industrial Europe. In T.H. Alston and C.H.E. Philpin (Eds.), The Brenner Debate: Agrarian Class Structure and Economic Development in Pre-Industrial Europe, pp. 10-63. Cambridge: Cambridge University Press.

Davidson, J. S. and Henley, D. (2007). The Revival of Tradition in Indonesian Politics: The Deployment of Adat from Colonialism to Indigenism. London: Routledge.

Donzelli, A. (2007). Copyright and Authorship: Ritual Speech and the New Market of Words in Toraja. In D. Berliner and R. Sarró (Eds.), Learning Religion: Anthropological Approaches, pp. 141-160. New York:

Berghahn Books.

Eliade, M. (1964). Shamanism: Archaic Techniques of Ecstasy. Translated by W. R. Trask. Princeton: Princeton University Press.

Graeber, D. (2001). Toward an Anthropological Theory of Value: The False Coin of Our Dreams. New York: Palgrave.

Harrington, M. H. (2014). Changing Exchanges: A Modern Siang Village amidst Resource Extraction in Regional Indonesia. Ph.D. diss. Asia Institute.

Haug, M. (2010). Poverty and Decentralisation in East Kalimantan: The Impact of Regional Autonomy on Dayak Benuaq Wellbeing. Freiburg: Centaurus Verlag.

Herrmans, I. (2015). Ritual Retellings: Luangan Healing Performances through Practice. New York: Berghahn Books.

Ingold, T. (2006). Rethinking the Animate, Re-animating Thought. Ethnos: Journal of Anthropology, 71 (1), 920 .

Keeler, W. (2001). Javanese: A Cultural Approach. Athens: Ohio University for International Studies.

Lambek, M. (2012). Religion and Morality. In D. Fassin (Ed.), A Companion to Moral Anthropology, pp. 341358. Malden: Wiley-Blackwell.

Lambek, M. (2013). The Value of (Performative) Acts. HAU: Journal of Ethnographic Theory 3 (2), 141-60.

Li, T. M. (2014). Land's End: Capitalist Relations on an Indigenous Frontier. Durham: Duke University Press.

Picard, M. (2011). Introduction: “Agama”, “Adat”, and Pancasila. In M. Picard and R. Madinier (Eds.), The Politics of Religion in Indonesia: Syncretism, Orthodoxy, and Religious Contention in Java and Bali, pp. 1-20. London: Routledge.

Rappaport, R. (1999). Ritual and Religion in the Making of Humanity. Cambridge: Cambridge University Press.

Reuter, T. (2009). Globalisation and Local Identities: The Rise of New Ethnic and Religious Movements in PostSuharto Indonesia. Asian Journal of Social Science 37, 857-871. 
Reuter, T. (2013). An Ancient Temple and a New King: Revitalization, Ritual and Politics in the Highlands of Bali. In T. Reuter and A. Horstmann (Eds.), Faith in the Future: Understanding the Revitalization of Religions and Cultural Traditions in Asia. Leiden: Brill.

Robbins, J. and D. Akin. (1999). An Introduction to Melanesian Currencies: Agency, Identity, and Social Reproduction. In D. Akin and J. Robbins (Eds.), Money and Modernity: State and Local Currencies in Melanesia, pp. 103-130. Pittsburg: Pittsburgh University Press.

Robbins, J. (2012). Cultural Values. In D. Fassin (Ed.), A Companion to Moral Anthropology, pp. 117- 132. Malden: Wiley-Blackwell.

Robbins, J. (2013). Monism, Pluralism, and the Structure of Value Relations: A Dumontian Contribution to the Contemporary Study of Value. HAU: Journal of Ethnographic Theory 3 (1), 99-115.

Rousseau, J. (2013). When Sudden Economic Change is not Traumatic: The Collapse of Meat Sharing in Central Borneo. Social Evolution \& History 12 (1), 78-87.

Sather, C. (2001). Seeds of Play, Words of Power: An Ethnographic Study of Iban Shamanic Chants. Kuala Lumpur: The Tun Jugah Foundation.

Schiller, A. (1997). Small Sacrifices: Religious Change and Cultural Identity among the Ngaju of Indonesia. New York: Oxford University Press.

Sillander, K. (2004). Acting Authoritatively: How Authority is Expressed Through Social Action among the Bentian of Indonesian Borneo. Helsinki: Helsinki University Press.

Sillander, K. (2011). Kinship and the Dialectics of Autonomy and Solidarity among the Bentian of Borneo. In T. Gibson and K. Sillander (Eds.), Anarchic Solidarity: Autonomy, Equality, and Fellowship in Southeast Asia, pp. 141-169. New Haven: Yale University Southeast Asia Studies.

Sutton, R. (1996). Interpreting Electronic Sound Technology in the Contemporary Javanese Soundscape. Ethnomusicology, 40(2), 249-268.

Strathern, M. (1988). The Gender of the Gift: Problems with Women and Problems with Society in Melanesia. Berkeley: University of California Press.

Weinstock, J. (1983). Kaharingan and the Luangan Dayaks: Religion and Identity in Central-East Borneo. Ph.D. dissertation, Cornell University.

Wood, E. M. (2002). The Origins of Capitalism: A Longer View. London: Verso. 


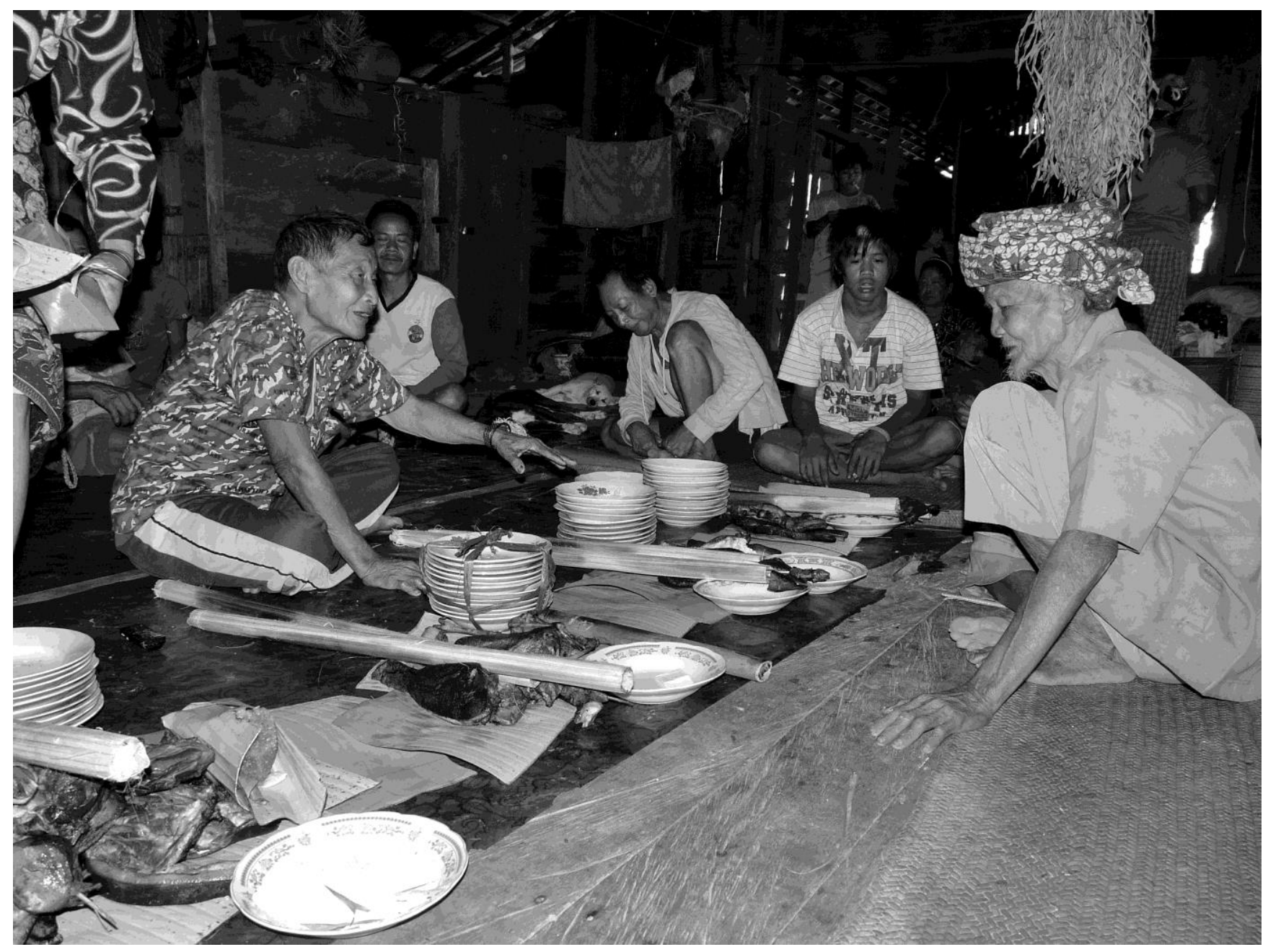

Figure 1. Ceremonial display of plates paid as compensation for ritual work. Sembulan village. Copyright: Isabell Herrmans 


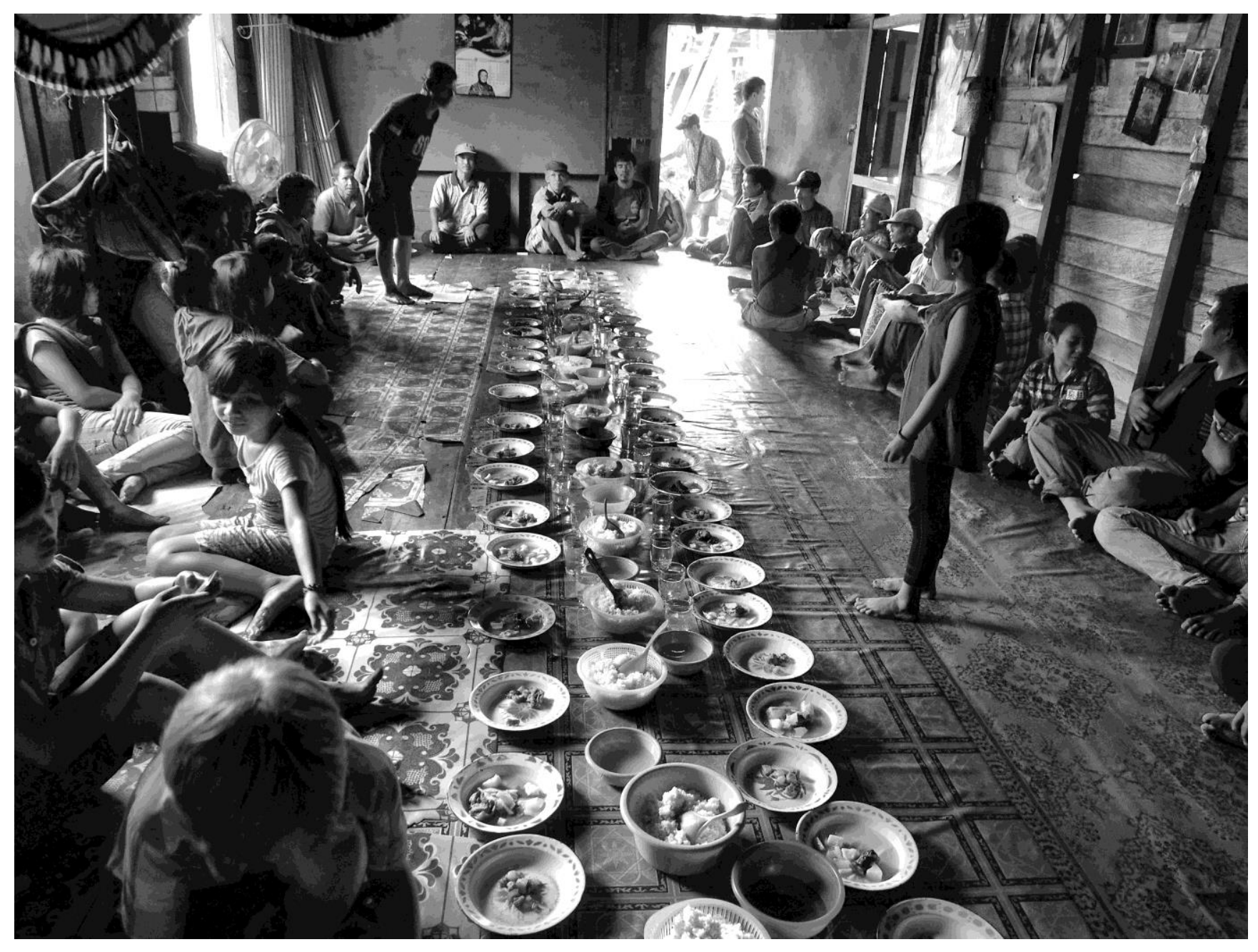

Figure 2. Ritual Sharing of Food. Muara Mea village.

Copyright: Isabell Herrmans 